\title{
ANALISA LAPORAN KEUANGAN \\ PADA PT. BANK RAKYAT INDONESIA (Persero) \\ Tbk CABANG PAINAN
}

\author{
Reno Patriani, Mariani St.B Tanjung \\ Akademi Keuangan dan Perbankan Padang \\ mstbtanjung@gmail.com
}

\begin{abstract}
ABSTRAK
Penelitian ini bertujuan untuk mengetahui dan menganalisa laporan keuangan pada PT. Bank Rakyat Indonesia (Persero) Tbk Cabang Painan. Teknik analisis data yang digunakan adalah teknik analisa data kuantitatif yang didapat dari laporan keuangan PT. Bank Rakyat Indonesia (Persero) Tbk Cabang Painan yang kemudian dianalisis dengan menggunakan dasar-dasar teoritis dari landasan teori yang sudah ada. Teknik yang digunakan adalah dengan menggunakan rasio-rasio yang berkaitan dengan analisis rasio keuangan perbankan yaitu rasio likuiditas, rasio rentabilitas dan rasio solvabilitas. Dari rasio likuiditas dapat diketahui bahwa Bank Rakyat Indonesia ( Persero ) Tbk Cabang Painan likuid karena mampu memenuhi kewajiban jangka pendeknya dari alat-alat likuid ( kas dan giro di BI ) yang ada dilihat dari cash ratio sebesar 14,7 \% dan RR sebesar 15,21 \%, dilihat dari LDR Bank ini mampu menyalurkan dana yang dihimpun sebesar $83,3 \%$ dan loan to asset ratio sebesar 58,61 \%. Dari rasio rentabilitas dapat diketahui bahwa Bank Rakyat Indonesia (Persero) Tbk Cabang Painan mampu menghasilkan laba kotor 49,4 \% dari setiap pendapatan operasionalnya ( gross profit margin ), laba bersih 18,22 \% dari pendapatan operasionalnya ( net profit margin ), keuntungan 17,78 \% bagi Bank / pemegang saham dari investasi yang ditanamkan ( ROE ) dan keuntungan 2,55\% dari total aktiva yang dikelola. Dari rasio solvabilitas yaitu kemampuan Bank untuk memenuhi kewajiban jangka panjangnya dapt diketahui bahwa Bank Rakyat Indonesia ( Persero ) Tbk Cabang Painan mampu untuk memenuhi kewajiban jangka panjangnya dilihat dari CAR yang mengukur kecukupan modal untuk menunjang aktiva yang mengandung atau menghasilkan resiko yaitu sebesar 16,77\% dan debt equity ratio yang mengukur kemampuan Bank dalam menutup sebagian atau seluruh hutang-hutangnya sebesar 18,06 \% dari modal sendiri.
\end{abstract}

Kata Kunci: Laporan Keuangan

\section{PENDAHULUAN}

Bank adalah badan usaha yang menghimpun dana dari masyarakat dalam bentuk simpanan dan menyalurkan ke masyarakat dalam bentuk kredit dan atau bentuk-bentuk lainnya dalam rangka meningkatkan taraf hidup rakyat banyak (Undang-undang Pasal 1 tentang Perbankan No. 10 tahun 1998). 
Selain itu peranan Bank sangat mempengaruhi kegiatan ekonomi suatu Negara. Bank dapat dikatakan sebagai darahnya perekonomian suatu Negara. Oleh karena itu kemajuan suatu Bank disuatu Negara dapat pula dijadikan ukuran kemajuan Negara yang bersangkutan. Semakin maju suatu Negara, maka semakin besar peranan perbankan dalam mengendalikan keuangan Negara tersebut.

Dalam menghadapi krisis finansial yang terjadi sekarang ini Bank baik milik pemerintah maupun swasta dituntut untuk lebih memaksimalkan kinerjanya dalam berbagai hal. Dalam melakukan hal tersebut di dalam lembaga keuangan diperlukan manajemen yang baik, yang bisa mengelola semuanya dengan maksimal agar mendapatkan keuntungan yang besar. Sekarang ini, tingkat perekonomian rakyat tidak stabil, ada Bank yang tidak mampu menghadapi kondisi saat sekarang ini yang mengakibatkan Bank tersebut collaps. Salah satu hal penting yang harus diperhatikan oleh Bank di Indonesia agar mampu mempertahankan kelangsungan hidup Bank itu sendiri pada kondisi krisis global ini yaitu dengan mengelola keuangannya secara baik. Hal ini akan dapat dilihat dari laporan keuangan yang disajikan.

Laporan keuangan ( financial statement) merupakan gambaran dari sebuah perusahaan pada waktu tertentu ( biasanya satu periode akuntansi ) dan memberikan gambaran tentang kondisi keuangan yang dicapai perusahaan dalam waktu tesebut.

Laporan keuangan dapat dijadikan bahan penguji dan pekerjaan bagi pembukuan dan sebagai alat menentukan atau menilai posisi keuangan Bank pada waktu tertentu. Hasil penilain ini akan sangat berguna pihak-pihak tertentu yang berhubungan langsung ( mempunyai kepentingan ) atau bagi mereka yang ingin menanamkan modalnya. Dengan menggunakan analisa laporan keuangan ini yang berupa ratio likuiditas, ratio rentabilitas dan ratio solvabilitas baik Bank maupun pihak-pihak yang berhubungan langsung akan bisa mengetahui apakah Bank ini dalam kondisi baik atau tidak.

Berdasarkan uraian diatas penulis tertarik untuk mengadakan penelitian mengenai analisa laporan keuangan PT. Bank Rakyat Indonesia (Persero) Tbk Cabang Painan dengan menggunakan rasio likuiditas, rentabilitas dan solvabilitas, dalam Tugas Akhir yang berjudul "Analisa Laporan Keuangan pada PT. Bank Rakyat Indonesia (Persero) Tbk Cabang Painan".

Berdasarkan uraian diatas, maka masalah yang penulis ajukan dalam penelitian ini adalah "Bagaimanakah analisa laporan keuangan pada PT. Bank Rakyat Indonesia (Persero) Tbk Cabang Painan ?“.

\section{METODE PENELITIAN}

\section{Teknik Pengumpulan Data}

1. Library research

Yaitu mengadakan penelitian kepustakaan dengan membahas literatur yang erat hubungannya dengan masalah yang penulis bahas pada tugas akhir ini.

2. Field research

Suatu penelitian untuk memperoleh data dan informasi dari laporan keuangan yang langsung diminta dari PT. Bank Rakyat Indonesia (Persero) Tbk Cabang Painan. 


\section{Teknik Analisa Data}

Teknik analisis data yang digunakan adalah teknik analisa data kuantitatif yang didapat dari laporan keuangan PT. Bank Rakyat Indonesia ( Persero ) Tbk Cabang Painan yang kemudian dianalisis dengan menggunakan dasar-dasar teoritis dari landasan teori yang sudah ada. Teknik yang digunakan adalah dengan menggunakan rasio-rasio yang berkaitan dengan analisis rasio keuangan perbankan yaitu rasio likuiditas, rasio rentabilitas dan rasio solvabilitas.

\section{LANDASAN TEORI}

\section{Laporan Keuangan}

Laporan keuangan merupakan akhir dari suatu proses pencacatan yang merupakan suatu ringkasan dari transaksi-transaksi keuangan yang terjadi selama satu periode akuntansi biasanya satu tahun. Laporan keuangan yang disajikan oleh Bank Umum untuk dipublikasikan kepada masyarakat berpedoman kepada Peraturan Bank Indonesia No.3/22/PBI tanggal 31 Desember 2001 tentang Transparansi kondisi keuangan Bank dan Surat Edaran Bank Indonesia No.3/30/DPNP tanggal 14 Desember 2001 tentang laporan keuangan Publikasi Triwulan dan Bulanan Bank Umum serta laporan tertentu yang disampaikan kepada Bank Indonesia.

Data yang dilaporkan dalam akuntansi keuangan bersifat historis yaitu mengenai kejadian yang telah lewat. Meskipun data akuntansi yang telah lalu namun data ini berguna untuk pengawasan dan perencanaan pada masa yang akan datang.

\section{Tujuan dan Manfaat Laporan Keuangan}

Tujuan dan manfaat laporan keuangan yang utama adalah memberikan gambaran keuangan perusahaan secara menyeluruh yang meliputi penentuan laba rugi dan posisi keuangan perusahaan. Sedangkan dalam Prinsip Akuntansi Indonesia (PAI) disebutkan laporan keuangan meliputi neraca, perhitungan laba rugi, laporan posisi keuangan dan catatan atas laporan keuangan.

Manfaat laporan keuangan tersebut dapat dinyatakan sebagai berikut :

1. Untuk mengetahui informasi keuangan yang dapat dipercaya mengenai aktiva dan kewajiban serta modal suatu perusahaan.

2. Untuk memberikan informasi yang dapat percaya mengenai perubahan dan aktiva netto ( aktiva dikurangi kewajiban ), suatu perusahaan yang timbul dari kegiatan usaha dalam rangka memperoleh laba.

3. Untuk memberikan informasi keuangan yang membantu pemakaian laporan dalam menaksir potensi perubahan dalam menaksir laba.

4. Menyediakan informasi penting lainnya yang relavan dengan kepentingan pemakai.

5. Memberikan informasi lainnya mengenai perubahan-perubahan dalam aktiva dan kewajiban suatu perusahaan, seperti informasi mengenai aktiva pembiayaan investasi.

Laporan keuangan yang telah disusun juga mengandung beberapa kelemahan yaitu sebagai berikut :

1. Akuntansi selalu mendasarkan diri pada biaya masa lampau sehingga mengakibatkan terjadi overstatet dalam penetapan laba perusahaan yang akan mengakibatkan terjadinya masalah modal pada inflansi.

2. Akuntansi yang berorientasi pada biaya historis. 
3. Akuntansi hanya memberikan diskripsi kepada hal-hal yang sudah terjadi saja.

4. Akuntansi tidak memberikan faktor-faktor finansial yang memperngaruhi perusahaan.

5. Akuntansi banyak menggunakan istilah teknis.

6. Laporan keuangan lebih menekankan bagaimana keadaan sebenarnya.

7. Akuntansi lebih merupakan seni dan kurang ilmiah.

8. Adanya metode akuntansi yang digunakan bermacam-macam yang menimbulkan variasi dalam mengukur sumber-sumber ekonomi yang tingkat kesuksesan antar perusahaan.

Jadi bagi mereka yang tidak memahami akuntansi tentu akan menganggap bahwa laporan keuangan itu suatu daftar yang berdasarkan fakta, yang memperhatikan nilai dari suatu perusahaan secara pasti dan sesuai dengan kondisi.

\section{Pihak-pihak yang Berkepentingan Terhadap Laporan Keuangan}

Laporan keuangan pada dasarnya adalah seni dari proses akuntansi yang dapat digunakan sebagai alat untuk berkomunikasi antar data keuangan atau aktivitas keuangan perusahaan dengan pihak-pihak yang berkepentingan tersebut adalah :

1. Pemilik Perusahaan

Pemilik perusahaan sangat berkepentingan terhadap laporan keuangan, terutama perusahaan yang managernya diserahkan kepada orang lain sehingga dengan demikian perusahaan yang dikelola oleh orang lain dapat dilihat kesuksesannya.

Maju mundurnya perusahaan tergantung kepada daya kerja dari manager perusahaan yang bersangkutan, jika hasil yang dicapai kurang memuaskan maka pemilik perusahaan yang terdiri dari pemegang saham mungkin akan mengganti manager atau menjual sahamnya. Keputusan yang diambil tergantung dari analisa pemilik perusahaan terhadap laporan keuangan perusahaannya.

2. Manager Perusahaan

Manager perusahaan berkepentingan terhadap laporan keuangan karena dengan mengetahui posisi keuangan pada periode yang lalu, manager dapat menyusun rencana yang lebih baik, memperbaiki sistem pengendalian dan pengawasan intern serta menentukan kebijaksanaan yang lebih tepat. Bagi manager yang diperlukan adalah bagaimana mencapai laba yang lebih tinggi, cara kerja yang efisien, aman dan terjaga baik, stuktur permodalan yang cukup baik, serta mengetahui dari depan baik mengenai keuangan maupun operasinya. Dengan demikian laporan keuangan sangat sangat berperan untuk mempertanggungjawabkan kepercayaan yang telah dilimpahkan kepadanya oleh pemilik perusahaan.

3. Investor

Investor berkepentingan terhadap laporan keuangan perusahaan karena dengan modal yang telah ditanamkan tersebut tentu mereka mengharapkan imbalan dari modal yang telah mereka tanamkan. Dari hasil laporan keuangan perusahaan investor akan dapat informasi bagaimana keadaan keuangan perusahaan yang akan memperngaruhi kebijaksanaan investor. 


\section{Kreditur}

Para kreditur terutama perbankan akan selektif memberikan kreditnya pada perusahaan yang menginginkan modal. Pihak perbankan akan melihat laporan keuangan sebagai alat dalam mengambil keputusan apakah pemberian kredit tersebut disetujui atau tidak.

\section{Pemerintah}

Biasanya oleh pemerintah laporan keuangan ini berguna untuk menentukan besarnya beban pajak yang akan ditanggung oleh perusahaan.

\section{Analisa Laporan Keuangan}

Analisa laporan keuangan menghubungkan angka-angka yang terdapat dalam laporan keuangan dengan angka-angka lainnya. Yang nantinya dapat menjelaskan tentang perubahan.

Proses analisa laporan keuangan dilakukan dengan penerapan alat-alat teknis analisa laporan keuangan dan tujuan untuk memperoleh informasi-informasi dan ukuran yang bermanfaat bagi pengambilan keputusan. Analisa laporan keuangan ini juga merupakan kegiatan untuk merubah data akuntansi yang banyak menjadi sederhana. Dapat menilai keadaan serta hasil perusahaan pada masa sekarang dan masa lalu serta dapat meramalkan keadaan perusahaan dimasa datang.

\section{Laporan Keuangan PT. Bank Rakyat Indonesia ( Persero ) Tbk Cabang Painan}

PT. Bank Rakyat Indonesia ( Persero ) Tbk Cabang Painan setiap tahunnya mengeluarkan laporan keuangan yaitu neraca dan perhitungan laba rugi. Dalam pembahasan ini, laporan keuangan yang diperlukan adalah laporan keuangan tahun 2008 baik untuk neraca maupun laba rugi.

Dalam penyajiannya, aktiva dan kewajiban dalam neraca Bank tidak dikelompokan menurut lancar atau tidak lancar namun sedapat mungkin tetap disusun menurut tingkat likuiditas dan jatuh tempo. Setiap aktiva produktif disajikan di neraca sebesar jumlah bruto dari tagihan atau pendapatan Bank dikurangi dengan penyisihan penghapusan yang dibentuk untuk menutupi kemungkinan kerugian yang timbul dari masing-masing aktiva produktif yang bersangkutan.

Laporan laba / rugi Bank disusun dalam bentuk berjenjang ( multiple step ) yang menggambarkan pendapatan atau beban yang berasal dari kegiatan utama Bank dan kegiatan lainnya. Cara penyajian laporan laba / rugi Bank antara lain wajib memuat secara rinci unsur pendapatan dan beban, unsur pendapatan dan beban harus dibedakan antara pendapatan beban yang berasal dari kegiatan operasional dan non operasional.

Penulis mengambil laporan keuangan untuk satu periode supaya dapat memberikan informasi mengenai perkembangan PT. Bank Rakyat Indonesia (Persero) Tbk Cabang Painan pada tahun 2008. 
Tabel 1

BRI Cabang Painan

Neraca

Periode 31 desember 2008

(dalam jutaan rupiah)

\begin{tabular}{|c|c|c|c|}
\hline \multicolumn{2}{|l|}{ AKTIVA } & \multicolumn{2}{|l|}{ PASSIVA } \\
\hline Kas & 165.406 & Giro & 811.564 \\
\hline Giro pada BI & 146.954 & Kewajiban segera lainnya & 71.000 \\
\hline Giro pada Bank lain & 501.328 & Tabungan & 743.953 \\
\hline Penempatan pada Bank lain & 25.122 & Deposito berjangka & 497.704 \\
\hline PPAP-Penempatan pada & 645.434 & Sertifikat deposito & 3.134 \\
\hline Bank lain & & Simpanan dari Bank lain & 105.309 \\
\hline Surat berharga yang dimiliki & 8.491 & Surat berharga yang & 195.884 \\
\hline $\begin{array}{l}\text { PPAP-Surat berharga yang } \\
\text { dimiliki }\end{array}$ & 28.646 & $\begin{array}{l}\text { diterbitkan } \\
\text { Pinjaman yang diterima }\end{array}$ & 210.422 \\
\hline Kredit yang diberikan & 13.857 & Estimasi kerugian komitmen & 225 \\
\hline PPAP-Kredit yang diberikan & 1.842 .796 & \& kontigensi & \\
\hline Penyertaan & 63.686 & Beban bunga yang masih & 20.883 \\
\hline PPAP-Penyertaan & 551 & harus dibayar & \\
\hline $\begin{array}{l}\text { Pendapatan yang masih } \\
\text { akan diterima }\end{array}$ & 3 & $\begin{array}{l}\text { Taksiran pajak penghasilan } \\
\text { Kewajiban lain-lain }\end{array}$ & $\begin{array}{c}3.328 \\
49.571\end{array}$ \\
\hline Biaya dibayar dimuka & 4.687 & Modal pinjaman & 660 \\
\hline Aktiva tetap & 51.140 & Modal disetor & 163.594 \\
\hline Akumulasi & 23.014 & Selisih kembali aktiva tetap & 10.580 \\
\hline aktiva tetap & & Saldo laba & 280.333 \\
\hline Aktiva lain & 6.119 & & \\
\hline Jumlah & 3.168.012 & Jumlah & 3.168.012 \\
\hline
\end{tabular}

Sumber : BRI Cabang Painan 
Tabel 2

BRI Cabang Painan

Laporan Laba Rugi

Periode 31 desember 2008

(dalam jutaan rupiah)

\begin{tabular}{|c|c|}
\hline Keterangan & 31 desember 2008 \\
\hline Pendapatan & \\
\hline Pendapatan operasional & \\
\hline Hasil bunga & 421.395 \\
\hline Provisi dan komisi & 22.108 \\
\hline Jumlah pendapatan operasional & 443.503 \\
\hline Pendapatan non operasional & 13.501 \\
\hline & 457.004 \\
\hline Biaya & \\
\hline Biaya operasional & \\
\hline Biaya bunga & 221.176 \\
\hline Penyusutan aktiva produktif & 3.087 \\
\hline Biaya estimasi kerugian komitmen & 151 \\
\hline Jumlah By. operasional & 224.414 \\
\hline Biaya non operasional & 114.351 \\
\hline & $\underline{338.765}$ \\
\hline Laba sebelum pajak & 118.239 \\
\hline Taksiran pajak penghasilan & 37.404 \\
\hline Saldo laba akhir periode & 80.835 \\
\hline
\end{tabular}

Sumber : BRI cabang Painan

Neraca yang diperbandingkan (Comporative Balance Shee) yang menunjukan aktiva, hutang serta modal Bank itu sendiri. Sedangkan laporan laba rugi yang diperbandingkan ( Comporative Income Statement ) yang menunjukan penerimaan, pengeluaran atau biaya-biaya.

Analisa Ratio Laporan Keuangan PT. Bank Rakyat Indonesia ( Persero ) Tbk

\section{Cabang Painan.}

Mengadakan analisa hubungan dari berbagai pos dalam suatu laporan keuangan adalah dasar untuk dapat melakukan interprestasi terhadap kondisi keuangan dan hasil suatu bidang. Dengan menggunakan laporan yang diberikan, termasuk data tentang perubahan yang terjadi dalam jutaan rupiah, persentase, penganalisa menyadari beberapa ratio secara individu akan membantu dalam menganalisa dan menginterpretasikan posisi keuangan suatu perusahaan.

Ratio menggambarkan suatu hubungan atau pertimbangan antar suatu jumlah tertentu dengan jumlah lainnya dan menggunakan analisa ratio, ratio ini akan dapat menjelaskan atau memberikan gambaran kepada penganalisis tentang baik buruknya keadaan keuangan perusahaan. Dengan menggunakan analisa ratio dimungkinkan untuk menentukan likuiditas, rentabilitas, dan solvabilitas.

\section{Analisa Ratio Likuiditas}

Likuiditas adalah kemampuan perusahaan untuk menyediakan alat-alat yang likuid (yang mudah dijual/diuangkan) guna menjamin pengembalian hutang-hutang 
jangka pendek pada waktunya atau hutang-hutang jangka panjang yang telah / akan jatuh tempo (Farid Djahidin 1982 : 101).

Keadaan ini sangat diperlukan oleh para kreditur, bank atau calon-calon kreditur baik sebagai ukuran kemampuan pengembalian pinjamannya atau ukuran kemampuan perusahaan membayar bunganya. Mekanisme (teknik-teknik) perhitungan yang digunakan adalah

1) Cash Ratio

Merupakan perbandingan ( ratio ) antara jumlah alat-alat likuid ( kas dan Giro pada BI ) yang dimiliki Bank pada suatu periode terhadap kewajiban segera yang harus dibayar ( giro, tabungan, deposito dan kewajiban segera lainnya ). Rasio ini digunakan untuk mengukur kemampuan Bank dalam membayar kembali simpanan nasabah ( deposan ) pada saat ditarik dengan alat likuid yang dimilikinya.

$\begin{aligned} \text { Cash ratio } & =\frac{\text { Jumlah Alat Likuid }}{\text { Kewajiban segera }} \times 100 \% \\ & =\frac{312.360}{2.124 .221} \times 100 \% \\ & =14,7 \%\end{aligned}$

Dari cash ratio dapat kita ketahui bahwa Bank ini mampu memenuhi kewajiban segera harus dibayar dengan 14,7\% dari alat-alat likuid yang di dimilikinya. Semakin tinggi persentase yang di peroleh dari cash ratio semakin bagus artinya Bank akan lebih mampu untuk memenuhi kewajiban segeranya.

2) Reserve Requiment ( $R R$ )

Reserve requiment atau lebih dikenal dengan simpanan wajib giro minimum yang wajib dipelihara dalam bentuk giro Bank Indonesia oleh Bank Rakyat Indonesia Cabang Painan. Berdasarkan Surat Edaran Bank Indonesia No. 23/17/BPPP tanggal 28 Februari 1996, besarnya RR adalah 2\%. Terhitung sejak tanggal 1 Februari 1996, besarnya RR adalah 3\% dan sejak tahun 1997 menjadi 5\%. Untuk mengetahui besarnya RR dapat menggunakan perbandingan sebagai berikut :

$\begin{aligned} \text { Reserve Requiment } & =\frac{\text { Jumlah Alat Likuid }}{\text { Jumlah DP3 }} \times 100 \% \\ & =\frac{312.360}{2.053 .221} \times 100 \% \\ & =15,21 \%\end{aligned}$

Dari ratio ini dapat diketahui bahwa Bank Rakyat Indonesia Cabang Painan menyisihkan dana pihak ketiga ( giro, tabungan dan deposito ) dalam bentuk giro di Bank Indonesia yang merupakan giro wajib minimum yang harus dipelihara sebesar 15, $21 \%$ pada periode tahun 2008.

3) Loan to Deposit Ratio ( LDR )

LDR ini menunjukan tingkat kemampuan Bank dalam menyalurkan dana pihak ketiga yang dihimpun oleh Bank Rakyat Indonesia cabang painan. Maksimal LDR yang ditetapkan oleh Bank Indonesia adalah sebesar 110\%, semakin tinggi rasio tersebut memberikan indikasi semakin rendah kemampuan likuiditasnya. 


$$
\begin{aligned}
\text { LDR } & =\frac{\text { Jumlah Kredit yang Diberikan }}{\text { Total DP3+Modal inti }} \times 100 \% \\
& =\frac{1.856 .658}{2.216 .815} \times 100 \% \\
& =83,8 \%
\end{aligned}
$$

Jadi besarnya LDR yang diperoleh oleh Bank Rakyat Indonesia Cabang Painan 83,8 \% artinya Bank tersebut mampu menyalurkan dana yang dimilikinya dari dana pihak ketiga ditambah dengan modal sendiri sebesar $83,8 \%$.

4) Loan to Asset Ratio

Rasio yang digunakan untuk mengukur tingkat likuiditas Bank yang menunjukan kemampuan Bank untuk memenuhi permintaan kredit dengan menggunakan total asset yang dimiliki Bank. Dengan kata lain rasio ini merupakan perbandingan seberapa besar kredit yang diberikan Bank dibandingkan dengan besarnya total asset yang dimiliki Bank. Semakin tinggi rasio ini, tingkat likuiditasnya semakin kecil karena jumlah asset yang diperlukan untuk membiayai kreditnya menjadi semakin besar.

$$
\begin{aligned}
\text { Loan to Asset Ratio } & =\quad \frac{\text { Jumlah Kredit yang Diberikan }}{\text { Jumlah Asset }} \times 100 \% \\
& =\quad \frac{1.856 .658}{3.168 .012} \times 100 \% \\
& =58,61 \%
\end{aligned}
$$

Dari perhitungan diatas diperoleh loan to asset ratio sebesar 58,61\% artinya Bank mampu menyalurkan kredit 58,61\% dari total asset yang dikelola selama tahun 2008.

\section{Analisa Ratio Rentabilitas}

Rentabilitas adalah kemampuan perusahaan untuk menghasilkan laba selama periode tertentu ( Suad Husnah 1991 : 214 ). Jadi rasio rentabilitas merupakan pengukuran tingkat efisiensi usaha dan profitabiltas yang dicapai oleh Bank atau mengukur kemampuan Bank dalam menghasilkan laba. Dalam analisa ini akan dicari hubungan yang timbal balik antara pos-pos yang ada pada income statement itu sendiri maupun hubungan timbal balik dengan pos-pos yang ada pada neraca Bank guna mendapatkan berbagai indikasi yang berguna untuk mengukur efisiensi dan profotabilitas Bank. Mekanisme ( teknik-teknik ) perhitungan yang digunakan adalah

1) Gross Profit Margin

Artinya untuk mengetahui presentase dari laba atas kegiatan usaha yang murni dari Bank yang bersangkutan sebelum dikurangi dengan biayabiaya personal, biaya kantor dan biaya overhead lainnya.

$$
\begin{aligned}
\text { Gross Profit Margin } & =\frac{\text { Operating income-Operating expense }}{\text { Operating income }} \times 100 \% \\
& =\frac{443.503-224.414}{443.503} \times 100 \% \\
& =49,4 \%
\end{aligned}
$$

Dari gross profit margin ini akan diketahui besarnya keuntungan / laba kotor atas kegiatan Bank yang diperoleh per Rp. 1 penjualan. Dari laporan laba rugi Bank Rakyat Indonesia cabang Painan dapat dihitung gross profit 
margin yaitu 49,4\%. Jadi Bank Rakyat Indonesia cabang Painan ini dapat menghasilkan laba / keuntungan sebesar 49,4\% dari setiap 1 rupiah penjualan yang dilakukan pada tahun 2008, semakin tinggi gross profit margin semakin bagus bagi Bank itu sendiri karena mampu menghasilkan keuntungan lebih tinggi.

2) Net Profit Margin

Net profit margin adalah rasio yang membandingkan antara laba bersih setelah pajak dengan penjualan atau pendapatan operasional yang dilakukan dalam satu periode.

$\begin{aligned} \text { Net Profit Margin } & =\frac{\text { Net income }}{\text { Operating income }} \times 100 \% \\ & =\frac{80.835}{443.503} \times 100 \% \\ & =18,22 \%\end{aligned}$

Dari net profit margin ini akan diketahui besarnya keuntungan / laba bersih (netto) yang diperoleh per Rp. 1 penjualan. Dari perhitungan net profit margin ini diketahui Bank Rakyat Indonesia cabang Painan mampu menghasilkan laba bersih (netto) 18,22 \% atas kegiatan usaha yang murni dari Bank sebelum dikurangi biaya-biaya operasional dan biaya overhead lainnya. Semakin tinggi net profit margin yang diperoleh semakin baik karena Bank tersebut mampu menghasilkan laba bersih yang tinggi.

3) Return On Equity Capital ( ROE )

ROE adalah untuk mengukur kemampuan manajemen dalam mengelola capital yang tersedia untuk mendapatkan net income dan juga bisa dikatakan untuk mengukur persentase laba yang diperoleh atas investasi yang dilakukan pemegang saham. Rasio ini sangat penting bagi para pemilik Bank / pemegang saham Bank.

$$
\begin{aligned}
\text { ROE } & =\frac{\text { Net income }}{\text { Equity capital }} \times 100 \% \\
& =\frac{80.835}{454.507} \times 100 \% \\
& =17,78 \%
\end{aligned}
$$

Dari rasio Return On Equity Capital dapat diketahui bahwa Bank Rakyat Indonesia cabang Painan mampu mendapatkan keuntungan 17,78 \% bagi Bank / pemegang saham dari total asset yang dimiliki dalam satu periode.

4) Return On Total Asset ( ROA )

Merupakan perbandingan antara pendapatan bersih dengan total aktiva yang ada. Rasio ini digunakan untuk mengukur kemampuan manajemen Bank dalam memperoleh laba dari asset yang ada.

$$
\begin{array}{rlr}
\text { ROA } & =\frac{\text { Net income }}{\text { Total asset }} \quad \times 100 \% \\
& =\frac{80.835}{3.168 .012} & \\
& =2,55 \%
\end{array}
$$


Dari rasio Return On Total Asset ini dapat diketahui bahwa Bank Rakyat Indonesia cabang Painan mampu menghasilkan laba bersih 2,55\% dari total aktiva yang dikelola dalam satu periode selama tahun 2008.

Perubahan / kenaikan-penurunan rasio ini dapat terjadi karena :

a. Lebih banyak asset yang digunakan untuk kredit sehingga akan menambah pendapatan dalam skala yang lebih besar.

b. Adanya kemampuan manajemen untuk mengalihkan surat-surat berharga ( port folio ) ke jenis yang menghasilkan pendapatan yang lebih tinggi.

c. Adanya kenaikan tingkat bunga secara umum.

d. Adanya pemanfaatan asset-asset yang semula tidak produktif menjadi asset yang produktif.

Dari hasil perhitungan rasio yang mengukur kemampuan Bank Rakyat Indonesia ( Persero ) Tbk Cabang Painan dalam menghasilkan pendapatannya dengan menggunakan Gross Profit Margin, Net Profit Margin, Return On Equity Capital ( ROE ), Return On Total Asset ( ROA ) hasilnya bagus karena Bank Rakyat Indonesia ( Persero ) Tbk Cabang Painan mampu menghasilkan laba dari total aktiva yang dikelolanya selama tahun 2008.

\section{Analisa Ratio Solvabilitas}

Analisa ratio solvabilitas adalah analisis yang digunakan untuk mengukur kemampuan Bank dalam memenuhi kewajiban jangka panjangnya atau kemampuan Bank untuk memenuhi kewajiban-kewajiban likuidasi Bank. Disamping itu, rasio ini digunakan untuk mengetahui perbandingan antara volume dana yang diperoleh dari berbagai hutang baik jangka pendek maupun jangka panjang serta sumber-sumber lain di luar modal Bank sendiri dengan volume penanaman dana tersebut pada berbagai jenis aktiva yang dimiliki Bank. Beberapa ratio yang diuraikan antara lain :

1) Capital Adequacy Ratio ( CAR )

CAR dalah rasio yang memperlihatkan seberapa jauh seluruh aktiva Bank yang mengandung resiko ( kredit, penyertaan, surat berharga, tagihan pada Bank lain ) ikut dibiayai dari dana modal sendiri Bank disamping memperoleh dana-dana dari sumber-sumber diluar Bank seperti dana masyarakat, pinjaman, dan lain-lain. Dengan kata lain CAR adalah rasio yang mengukur kecukupan modal untuk menunjang aktiva yang mengandung atau menghasilkan resiko ( total hutang dan surat-surat berharga ).

$\begin{aligned} \text { CAR } & =\frac{\text { Modal Bank }}{\text { Total Hutang + Surat-surat Berharga }} \times 100 \% \\ & =\frac{455.167}{2.712 .752} \times 100 \% \\ & =16,77 \% \\ & \text { Ratio ini menunjukan kemampuan permodalan untuk menutupi }\end{aligned}$
kemungkinan rugi atas kredit yang diberikan serta kerugian pada investasi surat-surat berharga. Jadi Bank Rakyat Indonesia ( Persero ) Tbk cabang Painan mampu menjamin total hutang dan surat-surat berharga yang dimiliki sebesar 16,77\% dari modal yang ada selama periode tahun 2008. 


\section{2) Debt to Equity Ratio}

Adalah ratio yang digunakan untuk mengukur kemampuan Bank dalam menutup sebagian atau seluruh hutang-hutangnya, baik jangka pendek maupun jangka panjang dengan dana yang berasal dari modal sendiri.

$\begin{aligned} \text { DER } & =\frac{\text { Jumlah Modal Sendiri }}{\text { Jumlah Hutang }} \times 100 \% \\ & =\frac{454.507}{2.516 .868} \\ & =18,06 \%\end{aligned}$

Menunjukan bahwa Bank Rakyat Indonesia ( Persero ) Tbk cabang Painan mampu memenuhi kewajibannya / hutangnya 18,06 \% yang dij dari modal sendiri tanpa modal pinjaman.

\section{KESIMPULAN}

Bank Rakyat Indonesia ( Persero ) Tbk Cabang Painan mampu memenuhi kewajiban baik jangka pendek maupun jangka panjang dan mampu menghasilkan laba dari dana yang dihimpunnya.

1. Dari rasio likuiditas dapat diketahui bahwa Bank Rakyat Indonesia ( Persero ) Tbk Cabang Painan likuid karena mampu memenuhi kewajiban jangka pendeknya dari alat-alat likuid ( kas dan giro di BI ) yang ada dilihat dari cash ratio sebesar 14,7 \% dan RR sebesar 15,21\%, dilihat dari LDR Bank ini mampu menyalurkan dana yang dihimpun sebesar $83,3 \%$ dan loan to asset ratio sebesar 58,61\%.

2. Dari rasio rentabilitas dapat diketahui bahwa Bank Rakyat Indonesia (Persero) Tbk Cabang Painan mampu menghasilkan laba kotor 49,4 \% dari setiap pendapatan operasionalnya ( gross profit margin ), laba bersih $18,22 \%$ dari pendapatan operasionalnya ( net profit margin ), keuntungan 17,78 \% bagi Bank / pemegang saham dari investasi yang ditanamkan ( ROE ) dan keuntungan 2,55 \% dari total aktiva yang dikelola.

3. Dari rasio solvabilitas yaitu kemampuan Bank untuk memenuhi kewajiban jangka panjangnya dapt diketahui bahwa Bank Rakyat Indonesia ( Persero ) Tbk Cabang Painan mampu untuk memenuhi kewajiban jangka panjangnya dilihat dari CAR yang mengukur kecukupan modal untuk menunjang aktiva yang mengandung atau menghasilkan resiko yaitu sebesar 16,77 \% dan debt equity ratio yang mengukur kemampuan Bank dalam menutup sebagian atau seluruh hutang-hutangnya sebesar 18,06\% dari modal sendiri.

\section{DAFTAR PUSTAKA}

Afriyeni, A. (2019). Analisis Laporan Arus Kas Untuk Mengukur Kinerja Keuangan Pada PT. Pegadaian (Persero). https://doi.org/10.17605/OSF.IO/6XVZD

Afriyeni, A. (2019). Analisis Laporan Keuangan Berdasarkan Tingkat Profitabilitas Pada PT. Bank Perkreditan Rakyat LPN Tarantang Kabupaten Dharmasraya. https://doi.org/10.17605/OSF.IO/XBF5W 
Afriyeni, A. (2019). Analisis Laporan Keuangan Berdasarkan Likuiditas Pada PT. Bank Pembangunan Daerah Sumatera Barat Cabang Utama. https://doi.org/10.17605/OSF.IO/DA43J

Afriyeni, A. (2019). Analisis Rasio Keuangan Pada PT. Pegadaian (Persero) Cabang Ulak Karang. https://doi.org/10.17605/OSF.IO/Z9PW8

Afriyeni, A., \& Putri, Y. (2019). Analisis Laporan Keuangan Berdasarkan Tingkat Profitabilitas Pada PT. Bank Perkreditan Rakyat LPN Tarantang Kabupaten Dharmasraya. https://doi.org/10.31219/osf.io/rtgxe

Mardila, W., \& Afriyeni, A. (2019). Analisis Laporan Keuangan Berdasarkan Likuiditas Pada PT Bank Pembangunan Daerah Sumatera Barat Cabang Utama. https://doi.org/10.31219/osf.io/cjkbt

Amelia, I., \& Afriyeni, A. (2019). Analisis Kinerja Keuangan Berdasarkan Rasio Solvabilitas Pada PT. BPD Sumatera Barat. https://doi.org/10.31219/osf.io/tsrzw

Arifin, I. Z., \& Marlius, D. (2017). Analisis Kinerja Keuangan PT. Pegadaian Cabang Ulak Karang. https://doi.org/10.31227/osf.io/n2peu

Farid Djahidin, 1982, Analisa Laporan Keuangan, Ghalia Indonesia, Jakarta.

Handayani, M., \& Marlius, D. (2017). Analisis Tingkat Kesehatan PT. BPR Batang Kapas. https://doi.org/10.31227/osf.io/bq48z

Fernos, J (2017). Analisis Rasio Profitabilitas Untuk Mengukur Kinerja (Studi Kasus Pada PT. Bank Pembangunan Daerah Provinsi Sumatera Barat. Jurnal Pundi. Vol 01. No 02. https://doi.org/10.31575/jp.v1i2.25

Iswari, M., \& Fernos, J. (2019). Analisis Tingkat Kesehatan Bank Pada PT. Bank Pembangunan Daerah Sumatera Barat. https://doi.org/10.31227/osf.io/ja7ty

James \& Chatton, 2005, Memahami Laporan Keuangan, PPM, Jakarta.

Kasmir SE.MM, 2002, Dasar-dasar Perbankan, PT. Raja Grafindo Persada, Jakarta.

Oktavia, L., \& Fernos, J. (2019). Analisis Laporan Keuangan Berdasarkan Tingkat Rentabilitas Bank Perkreditan Rakyat (BPR) Batang Palangki. https://doi.org/10.31227/osf.io/tbqdv

Pramita, Y., \& Afriyeni, A. (2019). Analisis Rasio Keuangan Pada PT. Pegadaian (Persero) Cabang Ulak Karang. https://doi.org/10.31219/osf.io/mj2ph 
Putri, Y. A., \& Marlius, D. (2018). Analisis Tingkat Kesehatan Bank Pada PT. Bank Perkreditan Rakyat (BPR) Jorong Kampuang Tangah Pariaman Cabang Padang. https://doi.org/10.31227/osf.io/r98pv

Rachnadi Usman, 2001, Aspek-aspek Hukum Perbankan di Indonesia, PT. Gramedia Pustaka Utama, Jakarta.

Rahmayeli, D. S., \& Marlius, D. (2017). Analisis Kinerja Keuangan Pada PT. Bank Perkreditan Rakyat (BPR) Batang Kapas Pesisir Selatan. https://doi.org/10.31227/osf.io/sz5db

Shanjaya, A. R., \& Marlius, D. (2017). Peranan Laporan Keuangan Dalam Kebijaksanaan Pemberian Kredit Kepada Calon Nasabah Pada PT. BPR Batang Kapas. https://doi.org/10.31227/osf.io/uxmg6

Suad Husnah, Drs, MBA, 1991, Manajemen Keuangan dan Penerapan, Edisi Kedua, BPEF Yogyakarta.

Suherti, E., \& Fernos, J. (2019). Analisa Rasio Terhadap Laporan Keuangan Pada PT. Bank Pembangunan Daerah Sumatera Barat. https://doi.org/10.31227/osf.io/9zte8

Teguh Pudjo Mulyono, 1995, Analisa Laporan Keuangan Perbankan, Djambatan, Jakarta.

Thomas Suyatno, 1997, Kelembagaan Perbankan, PT. Gramedia Pustaka Utama, Jakarta

Undang-Undang tentang Perbankan No.10 tahun 1998 Tentang Perubahan Atas Undang-Undang No. 7 Tahun 1992 Tentang Perbankan. 